\title{
Pengembangan dan Optimasi Kapsul Mikrosfer Ekstrak Licorice sebagai Bentuk Sediaan Oral Extended Release Kanker Payudara
}

\author{
Farmasita Nabilla Cahyani $^{1^{*}, \text { Rachmawati Ardiana }}{ }^{1}$, Dewi Uswatun Khasanah', Adinda Sukma \\ Dewi ${ }^{1}$, Oktavia Rahayu Adianingsih ${ }^{1}$ \\ ${ }^{1}$ Departemen Farmasi, Jurusan Farmasi, Fakultas Kedokteran, Universitas Brawijaya, Malang, Indonesia
}

\begin{tabular}{l}
\hline INFO ARTIKEL \\
\hline Penerimaan \\
naskah: 02 \\
Oktober 2021 \\
Penerimaan \\
naskah revisi: 14 \\
Desember 2021 \\
Disetujui untuk \\
dipublikasikan: \\
18 Desember \\
2021
\end{tabular}

Kata kunci : Kapsul Mikrosfer, Licorice, Kanker Payudara, HMGB1

\section{A B S T R A K}

Kanker payudara adalah kanker dengan angka kejadian tertinggi pada wanita di dunia berdasarkan data GLOBOCAN 2020. Protein yang terlibat dalam proses metastasis pada kanker adalah high mobility group box 1 (HMGB1). Licorice (Glycyrrhiza glabra) dilaporkan memiliki efek farmakologi antikanker dan ekstrak etanol roastedlicorice dapat mengurangi viabilitas metastasis sel kanker. Sistem penghantaran mikrosfer merupakan serbuk padat terdiri dari polimer, crosslinker, dan bahan aktif yang dapat memberikan efek terapeutik diperpanjang. Penelitian ini bertujuan untuk memprediksi kemampuan licorice menghambat protein HMGB1 melalui molecular docking study dan mengetahui konsentrasi crosslinker natrium tripolifosfat yang paling optimal dalam formula kapsul mikrosfer ekstrak licorice. Metode penelitian dilakukan dengan uji in silico berupa molecular docking dan uji ADMET, formulasi kapsul mikrosfer ekstrak licorice dengan variasi konsentrasi natrium tripolifosfat 3\%, 6\%, dan 9\%, dan uji evaluasi mutu sediaan meliputi morfologi dan ukuran, sifat alir, penetapan kandungan, organoleptik, kadar air, waktu hancur, dan keseragaman bobot. Data hasil uji evaluasi dianalisis secara statistik menggunakan uji Kruskal Wallis melalui IBM SPSS 28.0. Hasil yang diperoleh yakni senyawa glycyrrhetic acid, liquiritin apioside, dan liquiritin berpotensi menghambat protein HMGB1, glycyrrhetic acid dan licochalcone A merupakan substrat CYP450 3A4, dan delapan senyawa merupakan substrat P-gp dengan kelas toksisitas rendah. Kemudian tidak ada perbedaan yang signifikan pada hasil uji ketiga formula namun konsentrasi crosslinkernatrium tripolifosfat yang paling optimum dapat terlihat melalui uji evaluasi mutu sediaan. Kesimpulan penelitian ini adalah senyawa glycyrrhetic acid, liquiritin apioside, dan liquiritin dalam licorice berpotensi menghambat HMGB1 dan formula mikrosfer yang memenuhi uji evaluasi paling baik adalah formula dengan konsentrasi natrium tripolifosfat $3 \%$.

\section{Development and Optimation of Microsphere Capsule of Licorice Extract as Oral Extended Release Dosage Form for Breast Cancer}

Keywords:
Microsphere
Capsule,
Licorice, Breast
Cancer, HMGB1

\begin{abstract}
A B S TRACT
Breast cancer is cancer with the highest incidence in womenglobally based on GLOBOCAN 2020 data. The protein involved in the metastatic process in cancer is high mobility group box 1 (HMGB1). Licorice (Glycyrrhiza glabra) is reported to have anticancer pharmacological effects and ethanol extract of roasted licorice can reduce the metastatic viability of cancer cells. The microsphere delivery system is a solid powder composed of a polymer, crosslinker, and an active ingredient which can provide an extended therapeutic effect. This study aims to predict the ability of licorice to inhibit HMGB1 protein through a molecular docking study and to determine the optimal concentration of crosslinker sodium tripolyphosphate in the microsphere capsule formula of licorice extract. The research method was carried out by in silico test in the form of molecular docking and ADMET test, microsphere capsule formulation of licorice extract with variations in sodium tripolyphosphate concentration of $3 \%, 6 \%$, and $9 \%$, and evaluation of the quality of the preparation including morphology and size, flow properties, determination of content, organoleptic, moisture content, disintegration time, and weight uniformity. The data from the evaluation test were analyzed statistically using the Kruskal Wallis test through IBM SPSS 28.0. The results obtained are that glycyrrhetic acid, liquiritin apioside, and liquiritin have the potential to inhibit HMGB1 protein, glycyrrhetic acid and licochalcone A, which are substrates for CYP450 3A4, and eight compounds are P-gp substrates with low toxicity class. Then there was no significant difference in the test results of the three formulas, but the most optimum crosslinker sodium tripolyphosphate concentration could be seen through the evaluation test for the quality of the preparation. The conclusion of this study is that glycyrrhetic acid, liquiritin apioside, and liquiritin compounds in licorice have the potential to inhibit HMGB1 and the microsphere formula that meets the best evaluation test is the formula with $3 \%$ sodium tripolyphosphate concentration.
\end{abstract}




\section{Pendahuluan}

Kanker payudara memiliki prevalensi tertinggi yang terjadi pada wanita dan masih menjadi penyebab utama kematian pada kanker (1). Berdasarkan data GLOBOCAN tahun 2020, sebanyak 2.261.419 perempuan mengidap kanker payudara dengan rata-rata kematian 684.996 penduduk. Adanya kanker disebabkan oleh pembelahan sel yang tidak terkendali karena kerusakan deoxyribonucleic acid (DNA) yang menyebabkan terjadinya mutasi dari gen yang mengontrol pembelahan sel, sehingga sel normal berubah menjadi sel kanker (2). Pada kanker payudara, proliferasi sel yang tidak terkendali bermula di unit lobular duktus terminal (bagian fungsional payudara), yang disebabkan beberapa faktor, beberapa diantaranya adalah riwayat keluarga, mutasi gen yang terlibat dalam perbaikan DNA, faktor hormonal, gaya hidup yang kurang baik serta faktor lingkungan (3).

High mobility group box 1 (HMGB1) merupakan protein non histon yang berperan dalam proses transkripsi dan replikasi DNA, tumorigenesis, proliferasi, metastasis, inflamasi, serta berhubungan dengan patologi klinis adanya kanker pada manusia. Di luar inti sel, HMGB1 dapat berikatan dengan beberapa reseptor seperti receptor for advanced glycation end products (RAGE), toll-like receptors (TLRs) yang bertindak sebagai proliferasi, inflamasi, angiogenesis, menghambat antikanker dari antibodi host, dan berkontribusi pada tumorigenesis. Kandungan saponin seperti glycyrrhizin dilaporkan mampu menghambat pelepasan HMGB (4).

Tanaman licorice (Glycyrrhiza glabra) atau yang dikenal sebagai akar manis mengandung senyawa fitokimia berupa triterpen, saponin, dan flavonoid. Licorice (Glycyrrhiza glabra) dilaporkan memiliki efek farmakologi berupa antikarsinogenik, anti-mutagenesis, dan penekanan tumor (5). Hasil uji MTT pada sel kanker payudara MDA-MB-231 yang dikultur dengan ekstrak etanol roasted licorice selama 24 jam yakni ekstrak etanol dari roasted licorice dapat mereduksi viabilitas metastasis sel kanker payudara MDA-MB-231 dengan IC50 sebesar 8,9 mg/mL selama 24 jam (6).

Bentuk sediaan antikanker yang tersedia berupa injeksi intravena yang memerlukan tenaga ahli dalam pemberiannya serta dapat memberikan rasa sakit pada lokasi pemberian (7).Bentuk sediaan oral harus diminum beberapa kali untuk mempertahankan konsentrasi kadar plasma puncak sehingga meningkatkan risiko ketidakpatuhan pasien dan menggagalkan terapi. Maka, diperlukan teknologi sistem penghantaran oral extended release. Salah satu sistem penghantaran obat yang bisa digunakan adalah mikrosfer. Mikrosfer merupakan sediaan serbuk padat yang terdiri dari protein atau polimer dengan ukuran berkisar antara 1-1000 $\mu \mathrm{m}$. Pemilihan bentuk mikrosfer diantaranya dapat memberikan efek terapeutik yang berkepanjangan (extended release), sehingga dapat mengurangi pemberian dosis, meningkatkan ketersediaan hayati dan mengurangi risiko efek samping (8).

Komposisi mikrosfer terdiri dari polimer, crosslinker, dan bahan aktif.Mikrosfer juga diaplikasikan dalam sistem rilis terapi antikanker untuk meningkatkan efisiensi terapi (9). Mikrosfer dengan karakteristik pelepasan obat yang diperpanjang (extended release) melalui kapsul bertujuan untuk melindungi obat dari degradasi biologis dengan pembungkusan obat dalam polimer dan meningkatkan efektivitas pengobatan (10).Konsentrasi crosslinker harus dioptimasi untuk mendapatkan formula dengan profil rilis yang diinginkan. Umumnya crosslinker yang digunakan adalah natrium tripolifosfat yang bersifat tidak toksik.

Berdasarkan permasalahan yang ada, maka pada penelitian ini dilakukan uji molecular docking sebagai prediksi awal interaksi dari senyawa fitokimia licorice dengan protein HMGB1 (PDB 2LY4) yang berpotensi memicu apoptosis sel kanker payudara. Kemudian dari senyawa licorice dilakukan uji absorpsi, distribusi, metabolisme, ekskresi, dan toksisitas (ADMET) untuk mengetahui profil farmakokinetik dan toksisitas senyawa licorice. Uji toksisitasdilakukan melalui uji ames toxicity, uji hepatotoxicity, uji skin sensitization, LD50, dan klasifikasi toksisitassecara in silico.Selanjutnya dilakukan optimasi formula kapsul dengan sistem penghantaran mikrosfer berisi ekstrak licorice sebagai bentuk sediaan oral extended releasekanker payudara yang mampu meningkatkan angka eradikasi kanker payudara.

\section{Metode}

\section{Jenis Penelitian}

Penelitian ini menggunakan pendekatan riset empirik melalui platform virtual dan online dengan penelitian eksploratif berupa in silico yang bertujuan mengetahui jenis interaksi ligan ekstrak licorice terhadap reseptor HMGB1 serta profil farmakokinetika. Kemudian juga dilakukan penelitian menggunakan desain eksperimental dalam formulasi dan evaluasi sediaan kapsul mikrosfer di laboratorium sehingga dapat diketahui mutu fisik sediaan kapsul mikrosfer ekstrak licorice.

\section{Waktu dan Lokasi Penelitian}

Optimasikonsentrasi crosslinker dalam formulasi dan evaluasi mutu sediaan kapsul mikrosfer ekstrak licorice dilakukan di Laboratorium Farmasi Divisi Bahan Alam dan Farmasetika Farmasi Fakultas Kedokteran Universitas Brawijaya Malang dengan waktu penelitian yaitu 3 bulan dari bulan Juni 2021 hingga Agustus 2021.

\section{Instrument Penelitian \\ Molecular Docking dan Uji ADMET}

Alat yang digunakan pada uji molecular dockingserta ADMET adalah Software PyMol, PyRx, OpenBabel, LigPlot, pkCSM, Protox online tool, serta jaringan internet.

\section{Ekstraksi Licorice}

Alat dan bahan yang digunakan adalah serbuk simplisia licorice, etanol 96\%, kaleng maserasi, kain flanel, gelas ukur $1000 \mathrm{ml}$, beaker glass $600 \mathrm{ml}$, beaker glass $250 \mathrm{ml}$, labu ukur $1000 \mathrm{ml}$, corong pisah, kertas saring, rotary evaporator, dan cawan porselen.

\section{Formulasi}

Alat dan bahan yang digunakan dalam pembuatan formula mikrosfer adalah ekstrak kental licorice, etanol $96 \%$ 
(Panadia Lab), kitosan (CV Makmur), natrium tripolifosfat (Panadia Lab), asam asetat (CV Makmur), aquades (CV Makmur), $\mathrm{NaOH}$ (CV Makmur), syringe, kapsul gelatin keras ukuran 3, rotary evaporator, sonicator.

\section{Prosedur Penelitian \\ Molecular Docking dan Uji ADMET}

Struktur 3D senyawa dan protein didapatkan dari database PubChem (https://pubchem.ncbi.nlm.nih.gov/) dan diubah menjadi format pdb dengan aplikasi Openbabel. Struktur protein HMGB1 diperoleh dari database Uniprot (https://www.uniprot.org/) dengan (PDB 2LY4). Selanjutnya validasi struktur protein dilakukan melalui Ramachandran plot (http://molprobity.biochem.duke.edu/) (11). Kemudian dilakukan analisis prediksi obat potensial yang hasilnya harus memenuhi setidaknya dua dari lima aturan Lipinski (12).

Selanjutnya dilakukan molecular docking pada senyawa yang memenuhi aturan Lipinski terhadap protein HMGB1 (PDB 2LY4) dengan software PyRx dan didapatkan nilai binding affinity. Senyawa yang menunjukkan binding affinity yang lebih negatif dianalisis interaksi antara ligan dan protein HMGB1 dengan mengaplikasikan Ligplot software. Ligplot software digunakan untuk menentukan interaksi hidrofobik dan ikatan hidrogen antara ligan dan protein. Potensi penghambatan HMGB1 dapat dilihat dari adanya ikatan antara senyawa pada sisi aktif HMGB1, kemudian visualisasi molekuler dilakukan dengan aplikasi Pymol untuk mengetahui letak ikatan ligan dan protein (11). Uji ADMET dilakukan dengan mengubah senyawa ekstrak licorice menjadi format SMILE, kemudian dilakukan prediksi toksisitas melalui pKCSM (http://biosig.unimelb.edu.au/pkcsm/prediction), dan klasifikasi toksisitas melalui Protox online tool (https://toxnew.charite.de/protox_II/) (13).

\section{Ekstraksi}

Serbuk simplisia licorice dimaserasi dalam etanol $96 \%$ dengan perbandingan $1: 5$. Pada dua jam pertama dilakukan pengocokan lalu dibiarkan selama 24 jam. Dilakukan remaserasi sebanyak dua kali. Dilakukan penyaringan kemudian hasil maserasi dievaporasi menggunakan rotary evaporator dan didapatkan ekstrak kental.

\section{Formulasi Mikrosfer Ekstrak Licorice}

Rancangan formula pada penelitian ini ada tiga (Tabel 1), yaitu FI, FII, dan FIII dengan variasi konsentrasi pada crosslinker natrium tripolifosfat. Perbandingan ekstrak : kitosan yang digunakan adalah 1,5:2.

Tabel 1. Formula Mikrosfer Ekstrak Licorice

\begin{tabular}{|l|c|c|c|}
\hline \multicolumn{1}{|c|}{ Bahan } & FI & FII & FIII \\
\hline Kitosan (\% b/v) & 1 & 1 & 1 \\
\hline Asam asetat (\% v/v) & 2 & 2 & 2 \\
\hline Crosslinker Na TPP (\% b/v) & 3 & 6 & 9 \\
\hline
\end{tabular}

\section{Pembuatan Mikrosfer Ekstrak Licorice}

Pada penelitian ini digunakan metode gelasi ionik. Kitosan $1 \% \mathrm{w} / \mathrm{v}$ didispersikan dalam larutan asam asetat $2 \%$ $\mathrm{v} / \mathrm{v}\left(25^{\circ} \mathrm{C}, 500 \mathrm{rpm}, 4 \mathrm{jam}\right)$ hingga larut dengan magnetic stirrer. Larutan asam asetat sebelumnya diatur hingga $\mathrm{pH} 5$ menggunakan $\mathrm{NaOH}$. Ekstrak licorice dilarutkan dalam larutan kitosan dengan sonikatorbath hingga homogen. Larutan kitosan-ekstrak dimasukkan dalam syringe kemudian diteteskan secara perlahan pada larutan natrium tripolifosfat $3 \%, 6 \%$, dan 9\%. Dibiarkan selama 12 jam kemudian disaring dan dibilas dengan akuades sebanyak tiga kali. Mikrosfer yang terbentuk di oven selama 2 jam suhu $50^{\circ} \mathrm{C}$. Mikrosfer dimasukkan dalam kapsul gelatin keras ukuran 3.

\section{Evaluasi Mikrosfer Ekstrak Licorice}

1. Uji Organoleptik

Dilakukan uji terhadap penampilan fisik mikrosfer yang dihasilkan, meliputi warna, bau, dan rasa. Licorice memiliki rasa yang manis dengan bau yang khas serta berwarna cokelat (14).

2. Uji Ukuran dan Morfologi

Mikrosfer yang sudah disiapkan, diamati dengan mikroskop optik untuk mengetahui morfologi dari mikrosfer. Lalu mikrosfer didispersikan dalam etanol $96 \%$ dan diukur dengan particle size analyzer untuk menentukan ukuran partikel.

3. Uji Sifat Alir

Mikrosfer ditimbang $10 \mathrm{~g}$ dan dimasukkan ke dalam corong dengan bagian bawah corong tertutup. Setelah corong terisi oleh mikrosfer, tutup corong dibuka dan mikrosfer dibiarkan mengalir. Mikrosfer yang mengalir dipantau secara visual dan dihitung waktunya dengan menggunakan stopwatch. Mikrosfer yang telah mengalir dihitung sudut diam menggunakan rumus:

$$
\tan \alpha=h / \mathrm{r}
$$

Keterangan:

$\alpha \quad$ : sudut diam

h : tinggi kerucut dari tumpukan mikrosfer $(\mathrm{cm})$

$\mathrm{r} \quad$ : jari-jari tumpukan serbuk $(\mathrm{cm})$.

Laju alir dikatakan baik jika mampu mengalir $\geq 10 \mathrm{~g} /$ detik untuk $100 \mathrm{~g}$ serbuk sehingga laju alir $\leq 10$ detik. Aliran mikrosfer baik jika memiliki sudut diam $<30^{\circ}$.

4. Uji Kadar Air

Alat untuk menentukan kadar air adalah moisture analyzer/balance. Alat dipanaskan selama 10 menit dengan suhu $105^{\circ} \mathrm{C}$ yang dapat diatur pada alat. Sejumlah $2 \mathrm{~g}$ bahan diletakkan di atas piringan aluminium secara merata. Alat dinyalakan dan akan mati secara otomatis setelah mencapai kadar air yang stabil. Nilai kadar air dicatat dan kadar air untuk sediaan kapsul obat tradisional $\leq 10 \%(15)$.

5. Uji Waktu Hancur

Waktu hancur kapsul yang mengandung mikrosfer dilakukan dengan rakitan rak keranjang dan media air yang dipanaskan hingga $37^{\circ} \mathrm{C}$. Satu kapsul ditempatkan di setiap enam lubang pada tabung keranjang kemudian diletakkan cakram di atas kapsul. Waktu hancur untuk sediaan kapsul kurang dari atau sama dengan 30 menit (15).Uji Penetapan Kandungan

Mikrosfer sebanyak 10 mg dimasukkan ke labu ukur $10 \mathrm{ml}$, ditambahkan $10 \mathrm{ml}$ larutan metanol, diaduk, dan disaring. Filtrat dianalisis dengan spektrofotometer UV-Vis pada panjang gelombang $276 \mathrm{~nm}$ (16). 
6. Uji Keseragaman Bobot

Sebanyak 20 kapsul ditimbang menggunakan neraca analitik dan bobot rata-rata tiap isi kapsul dihitung. Kemudian bobot per kapsul ditimbang dan masing-masing bobot isi per kapsul terhadap bobot rata-rata tiap kapsul dihitung. Kapsul yang mengandung obat tradisional kering, tidak lebih dari dua kapsul dari 20 kapsul yang memiliki bobot menyimpang $10 \%$ dari bobot rata-rata dan tidak ada kapsul yang bobot isinya menyimpang lebih besar dari $25 \%$ dari bobot isi (15).

\section{Teknik Pengumpulan Data}

Pada penelitian ini, pengumpulan data dilakukan menggunakan teknik dokumentasi untuk moleculardocking, kemudian dilakukan analisis interaksi ikatan ligan dengan protein menggunakan software LigPlot. Teknik pengumpulan data yang digunakan untuk optimasi formula kapsul mikrosfer adalah observasi.

\section{Analisis Data}

Data dianalisis secara statistik menggunakan uji Kruskal Wallis melalui SPSS 28.0 pada batas kepercayaan $\alpha=0,05$. Sebelumnya dilakukan uji normalitas data dengan Shapiro Wilk. Uji statistik parameter Kruskal Wallis untuk melihat pengaruh variasi formula terhadap ukuran, sifat alir, penetapan kandungan, kadar air, waktu hancur, keseragaman bobot. Penentuan formula optimum karakterisasi mikrosfer yang dihasilkan dilihat melalui hasil uji evaluasi sediaan.

\section{Hasil dan Diskusi}

\section{Molecular Dockingdan Uji ADMET}

Struktur protein HMGB1 (PDB 2LY4) disterilisasi dari small molecule dan pengotor lainnya kemudian divalidasi dengan plot Ramachandran. Nilai yang baik untuk jumlah residu adalah $90-98 \%$. Hasil nilai residu yang diperoleh pada daerah favorit adalah 93,83\% sehingga model protein HMGB1 cukup baik dan dapat digunakan untuk analisis selanjutnya. Potensi senyawa licorice sebagai kandidat obat dianalisis dengan lima aturan Lipinski (Tabel 2). Aturan tersebut menjelaskan bahwa senyawa dengan probabilitas tinggi sebagai drug-like molecules harus mengikuti setidaknya dua aturan Lipinski ${ }^{[12]}$. Aturan Lipinski terdiri dari molecular weight $(\mathrm{MW}) \leq 500$ dalton, penerima ikatan hidrogen (HBD) $\leq 10$, donor ikatan hidrogen $(\mathrm{HBD}) \leq 5$, lipofilitas tinggi $(\operatorname{LogP}) \leq 5$, refraksi molar $(\mathrm{MR})$ antara 40-130. Analisis selanjutnya dapat menggunakan seluruh senyawa pada tabel 2 karena hasil menunjukkan bahwa seluruh senyawa dalam licorice memenuhi aturan Lipinski.

Interaksi antara protein HMGB1 dengan ligan dapat dilihat melalui analisis ikatan yang terbentuk (Tabel 3 dan 4). Ikatan hidrogen dan hidrofobik yang sama antara senyawa licorice dengan senyawa kontrol menandakan ikatan yang kuat.
Tabel 2. Hasil Potensi Senyawa Fitokimia Ekstrak Licorice sebagai Kandidat Obat

\begin{tabular}{|l|c|l|l|l|c|}
\hline \multirow{2}{*}{ Senyawa } & \multicolumn{5}{c|}{ Lipinsi Rule of Five } \\
\cline { 2 - 6 } & MW & HBD & HBA & LOGP & MR \\
\hline Liquiritin & 418.000 & 5 & 9 & 0,2774 & 101,26045 \\
\hline Isoliquiritin & 418.000 & 6 & 9 & 0,1726 & 103,97325 \\
\hline Liquiritigenin & 256.000 & 2 & 4 & 2,8042 & 68,530083 \\
\hline Isoliquiritigenin & 256.000 & 3 & 4 & 2,6994 & 71,242882 \\
\hline Liquiritin apioside & 550.000 & 7 & 13 & $-1,257$ & 127,90902 \\
\hline Glycyrrhetic acid & 470.000 & 2 & 4 & 6,4126 & 133,07156 \\
\hline Licochalcone A & 338.000 & 2 & 4 & 4,4660 & 99,353065 \\
\hline Glabridin & 324.000 & 2 & 4 & 4,0006 & 91,894569 \\
\hline
\end{tabular}

Tabel 3. Hasil Analisis interaksi ikatan antara senyawa Licorice dengan HMGB1

\begin{tabular}{|c|c|c|c|}
\hline No & Senyawa (Ligan) & $\begin{array}{l}\text { Aktivitas } \\
\text { (Binding } \\
\text { affinity) }\end{array}$ & Interaksi \\
\hline 1. & Glycyrrhetic acid & $-8,4$ & $\begin{array}{l}\text { Ikatan hidrogen: } \underline{\text { Arg9, }} \\
\text { Arg69, Met62 } \\
\text { Ikatan hidrofobik:Glu73, } \\
\text { Phe17, Gln20, Ala65, } \\
\text { Asp66 }\end{array}$ \\
\hline 2. & $\begin{array}{l}\text { Liquiritin } \\
\text { apioside }\end{array}$ & $-7,9$ & $\begin{array}{l}\text { Ikatan hidrogen: Arg9, } \\
\text { Glu73, Gln20, Thr21 } \\
\text { Ikatan hidrofobik: Arg69, } \\
\text { Pro8, Lys28,Lys27, } \\
\text { Pro31, Glu24, Glu25 }\end{array}$ \\
\hline 3. & Liquiritin & $-7,1$ & $\begin{array}{l}\text { Ikatan hidrogen: Arg9, } \\
\text { Arg69 } \\
\text { Ikatan hidrofobik: Lys7, } \\
\text { Pro8, Glys10, Glu73, } \\
\text { Phe17, Ala65 }\end{array}$ \\
\hline 4. & Isoliquiritin & $-7,0$ & $\begin{array}{l}\text { Ikatan hidrogen: Arg69, } \\
\text { Thr76 } \\
\text { Ikatan hidrofobik: Met62, } \\
\text { Thr21,Phe17, Arg9, Pro8, } \\
\text { Glu73, Lys7, Tyr77 }\end{array}$ \\
\hline 5. & Glabridin & $-6,9$ & $\begin{array}{l}\text { Ikatan hidrogen: Lys6 } \\
\text { Ikatan hidrofobik: Lys7, } \\
\text { Glu73, Pro8,Arg9, } \\
\text { Arg69, Glu24, Gln20, } \\
\text { Phe17, Thr21 }\end{array}$ \\
\hline 6. & Liquiritigenin & $-6,6$ & $\begin{array}{l}\text { Ikatan hidrogen: Arg69, } \\
\text { Thr21 } \\
\text { Ikatan hidrofobik: Glu25, } \\
\text { Gln20, Glu24, } \\
\text { Gly10,Pro8, Arg9, Glu73 }\end{array}$ \\
\hline 7. & Licochalcone A & $-6,4$ & $\begin{array}{l}\text { Ikatan hidrogen: } \text { Arg9 } \\
\text { Ikatan hidrofobik: Met62, } \\
\text { Ala65, Phe17, Glu24, } \\
\text { Thr21, Arg69, Gly10 }\end{array}$ \\
\hline 8. & Isoliquiritigenin & $-6,2$ & $\begin{array}{l}\text { Ikatan hidrogen: } \underline{\text { Arg9, }} \\
\text { Thr21 } \\
\text { Ikatan hidrofobik: } \text { Arg69, } \\
\text { Glu73, Gly10, Gln20, } \\
\text { Glu25,Glu24 }\end{array}$ \\
\hline 9. & Doxorubicin & $-7,1$ & $\begin{array}{l}\text { Ikatan hidrogen: Arg69, } \\
\text { Glu73, Lys6, Arg9 } \\
\text { Ikatan hidrofobik: Lys7, } \\
\text { Pro5, Glu24, Phe17, } \\
\text { Gln20, Pro8 } \\
\end{array}$ \\
\hline
\end{tabular}


Tabel 4. Visualisasi hasil uji molecular docking HMGB1 dengan senyawa aktif Licorice, (a) struktur senyawa aktif Licorice (b) overview (c) analisis interaksi yang terbentuk

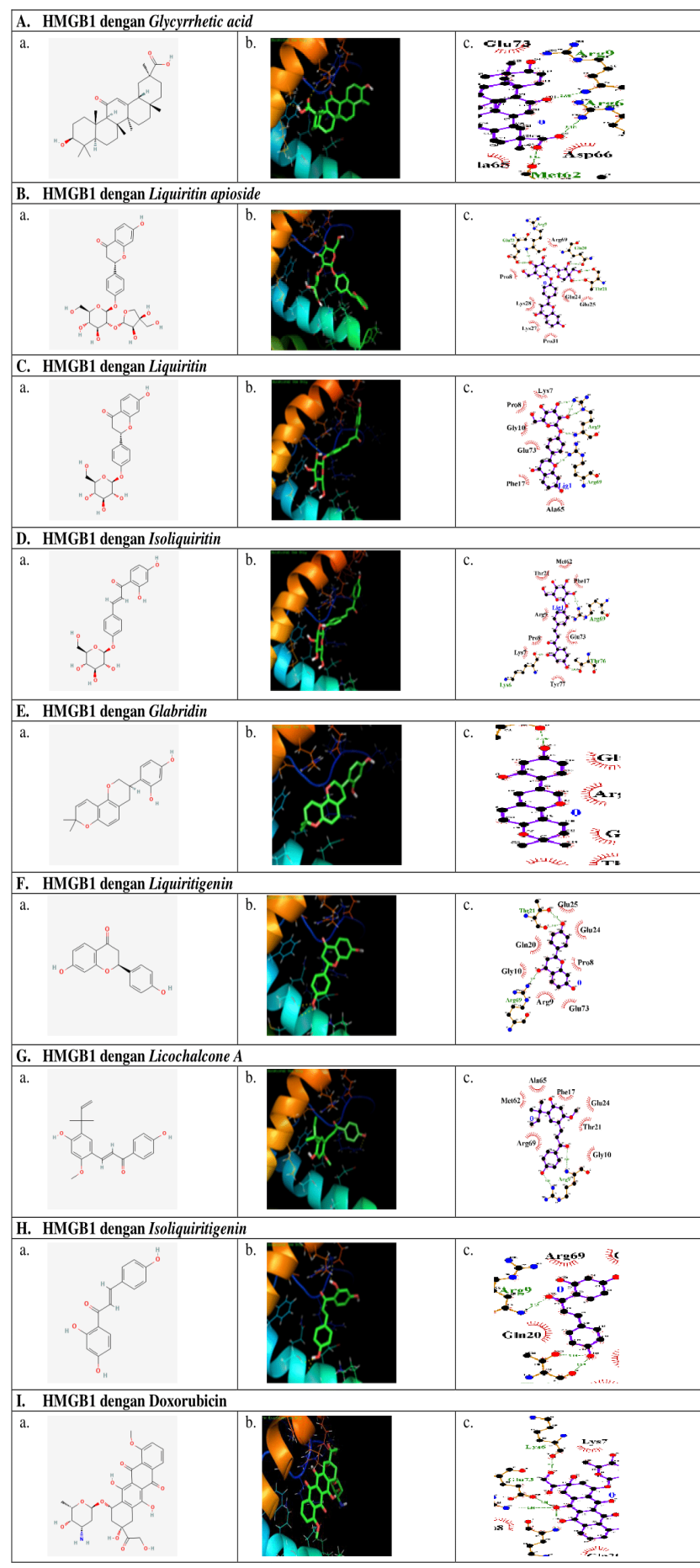

Untuk mengetahui toksisitas senyawa, dapat dilakukan dengan uji ames toxicity, uji hepatotoxicity, dan uji skin sensitization secara in silico menggunakan pkCSM. Uji ames toxicity merupakan metode yang digunakan secara luas untuk menilai potensi mutagenik senyawa dengan menggunakan bakteri. Uji in silico dapat juga dilakukan untuk melihat toksisitas per oral pada rodent (LD50). LD50 merupakan jumlah senyawa yang dapat menyebabkan kematian 50\% kelompok hewan coba. Selanjutnya klasifikasi toksisitas senyawa dilihat menggunakan Protox online tool.

Senyawa glycyrrhetic acid, licochalcone A, dan isoliquiritigenin pada licorice tidak menimbulkan efek mutagenik (Tabel 5). Seluruh senyawa licorice diprediksi tidak menyebabkan hepatotoksik serta tidak menimbulkan sensitisasi pada kulit. Berdasarkan Globally Harmonized System (GHS), klasifikasi toksisitas terbagi menjadi 6 kelas dan kelas 1-3 menandakan senyawa bersifat fatal dan toksik bila tertelan. Seluruh senyawa dalam licorice diprediksi mempunyai nilai LD50 pada rodent berkisar antara 560 sampai $4000 \mathrm{mg} / \mathrm{kg}$ dan termasuk kelas toksisitas 4 atau 5 yang berarti senyawa mempunyai efek toksisitas akut yang rendah.

Tabel 5. Prediksi in silico toksisitas antikanker menggunakan pkCSM dan protox online tool

\begin{tabular}{|l|c|c|c|c|c|}
\hline \multirow{2}{*}{$\begin{array}{c}\text { Senyawa } \\
\text { (Ligan) }\end{array}$} & \multicolumn{5}{|c|}{ Toksisitas } \\
\cline { 2 - 6 } & $\begin{array}{c}\text { Ames } \\
\text { toxicity }\end{array}$ & $\begin{array}{l}\text { Hepato } \\
\text { toxicity }\end{array}$ & $\begin{array}{c}\text { Skin } \\
\text { Sensiti } \\
\text { zation }\end{array}$ & $\begin{array}{c}\text { LD 50 } \\
\text { Acute } \\
\text { mg/kg }\end{array}$ & $\begin{array}{c}\text { Clas } \\
\text { ss }\end{array}$ \\
\hline $\begin{array}{l}\text { Glycyrrhetic } \\
\text { acid }\end{array}$ & Tidak & Tidak & Tidak & 560 & 4 \\
\hline $\begin{array}{l}\text { Liquiritin } \\
\text { apioside }\end{array}$ & Ya & Tidak & Tidak & 2300 & 5 \\
\hline Liquiritin & Ya & Tidak & Tidak & 2300 & 5 \\
\hline Isoliquiritin & Ya & Tidak & Tidak & 4000 & 5 \\
\hline Glabridin & Ya & Tidak & Tidak & 500 & 4 \\
\hline Liquiritigenin & Ya & Tidak & Tidak & 2000 & 4 \\
\hline Licochalcone A & Tidak & Tidak & Tidak & 1000 & 4 \\
\hline Isoliquiritigenin & Tidak & Tidak & Tidak & 3600 & 5 \\
\hline
\end{tabular}

Berdasarkan prediksi secara in silico yang telah dilakukan (Tabel 6), dapat diketahui bahwa delapan senyawa kandungan ekstrak licorice memenuhi kriteria adsorbsi, distribusi, metabolisme serta ekskresi. Seluruh senyawa selain glycyrrhetic acid merupakan substrat P-gp dan glycyrrhetic acid memiliki nilai $\log \mathrm{BB}>0,3$ yang diprediksi mampu menembus sawar darah otak. Glycyrrhetic acid dan licochalcone A merupakan substrat CYP450 3A4 dan seluruh senyawa bukan merupakan substrat rOCT2

Tabel 6. Prediksi in silico farmakokinetik antikanker menggunakan pkCSM dan protox online tool

\begin{tabular}{|c|c|c|c|c|c|c|c|}
\hline \multirow[t]{2}{*}{ Senyawa } & \multicolumn{5}{|c|}{ Farmakokinetik (ADMET) } & \multirow[b]{2}{*}{$\begin{array}{c}\text { rOC } \\
\text { T2 } \\
\text { subst } \\
\text { rate }\end{array}$} & \multirow[b]{2}{*}{$\begin{array}{c}\text { Tot } \\
\text { al } \\
\text { Cl }\end{array}$} \\
\hline & $\begin{array}{l}\text { P-gp } \\
\text { Subst } \\
\text { rate }\end{array}$ & $\begin{array}{c}P \text {-gp } \\
\text { inhib } \\
\text { itor }\end{array}$ & $\begin{array}{c}\text { BBB } \\
\text { permea } \\
\text { bility }\end{array}$ & $\begin{array}{c}\text { CYP45 } \\
\text { 0 } 3 A 4 \\
\text { substra } \\
\text { te/ } \\
\text { inhibit } \\
\text { or }\end{array}$ & $\begin{array}{c}C Y P \\
450 \\
2 C 9 \\
\text { inhib } \\
\text { itor }\end{array}$ & & \\
\hline $\begin{array}{l}\text { Glycyrrhe } \\
\text { tic acid }\end{array}$ & Tidak & $\begin{array}{c}\text { Tida } \\
\mathrm{k}\end{array}$ & 0,399 & $\begin{array}{c}\text { Ya/Tid } \\
\text { ak }\end{array}$ & $\begin{array}{c}\text { Tida } \\
\mathrm{k}\end{array}$ & Tidak & $\begin{array}{c}- \\
0.1 \\
14\end{array}$ \\
\hline Glabridin & $\mathrm{Ya}$ & $\mathrm{Ya}$ & 0.071 & $\begin{array}{l}\text { Tidak/ } \\
\text { Ya }\end{array}$ & Ya & Tidak & $\begin{array}{c}0,1 \\
59\end{array}$ \\
\hline $\begin{array}{l}\text { Licochalc } \\
\text { one A }\end{array}$ & $\mathrm{Ya}$ & Ya & -0.499 & $\mathrm{Ya} / \mathrm{Ya}$ & Ya & Tidak & $\begin{array}{l}0.4 \\
89\end{array}$ \\
\hline Liquiritin & Ya & $\begin{array}{c}\text { Tida } \\
\mathrm{k}\end{array}$ & $-1,213$ & $\begin{array}{l}\text { Tidak/ } \\
\text { Tidak }\end{array}$ & $\begin{array}{c}\text { Tida } \\
\mathrm{k}\end{array}$ & Tidak & $\begin{array}{l}0,4 \\
62 \\
\end{array}$ \\
\hline $\begin{array}{l}\text { Isoliquirit } \\
\text { in }\end{array}$ & $\mathrm{Ya}$ & $\begin{array}{c}\text { Tida } \\
\mathrm{k}\end{array}$ & $-1,284$ & $\begin{array}{l}\text { Tidak/ } \\
\text { Tidak } \\
\end{array}$ & $\begin{array}{c}\text { Tida } \\
\mathrm{k}\end{array}$ & Tidak & $\begin{array}{l}0,1 \\
65 \\
\end{array}$ \\
\hline $\begin{array}{l}\text { Liquiritin } \\
\text { apioside }\end{array}$ & $\mathrm{Ya}$ & $\begin{array}{c}\text { Tida } \\
\mathrm{k}\end{array}$ & $-1,284$ & $\begin{array}{l}\text { Tidak/ } \\
\text { Tidak }\end{array}$ & $\begin{array}{c}\text { Tida } \\
\mathrm{k} \\
\end{array}$ & Tidak & $\begin{array}{l}0,1 \\
65 \\
\end{array}$ \\
\hline $\begin{array}{l}\text { Liquiritig } \\
\text { enin }\end{array}$ & $\mathrm{Ya}$ & $\begin{array}{c}\text { Tida } \\
\mathrm{k}\end{array}$ & 0,1 & $\begin{array}{c}\text { Tidak/ } \\
\text { Ya }\end{array}$ & $\begin{array}{c}\text { Tida } \\
\mathrm{k}\end{array}$ & Tidak & $\begin{array}{l}0,0 \\
45\end{array}$ \\
\hline $\begin{array}{l}\text { Isoliquirit } \\
\text { igenin }\end{array}$ & $\mathrm{Ya}$ & $\begin{array}{c}\text { Tida } \\
\mathrm{k} \\
\end{array}$ & $-0,723$ & $\begin{array}{c}\text { Tidak/ } \\
\text { Ya } \\
\end{array}$ & $\mathrm{Ya}$ & Tidak & $\begin{array}{l}0,1 \\
21 \\
\end{array}$ \\
\hline
\end{tabular}

\section{Ekstrak Simplisia Licorice}


Hasil ekstraksi licorice yang didapatdari $720 \mathrm{~g}$ serbuk simplisia licorice dengan 3.6 liter etanol $96 \%$ adalah sebesar 214,1299 gram ekstrak kental, dengan persen rendemen yaitu sebesar $29,74 \%$.

\section{Evaluasi Sediaan Kapsul Mikrosfer Ekstrak Licorice Uji Organoleptik}

Uji evaluasi yang pertama dilakukan untuk menilai karakteristik mikrosfer dari ketiga formula adalah uji organoleptik. Uji organoleptik bertujuan untuk mengetahui karakteristik warna, rasa, dan bau dari mikrosfer ekstrak licorice.Licorice mengandung sejumlah metabolit sekunder antara lain triterpen, flavonoid, dan saponin. Saponin berperan dalam memberikan rasa manis pada licorice sehingga mikrosfer yang mengandung ekstrak licorice dapat terasa manis (14). Pada hasil uji organoleptik (Tabel 7), didapatkan rasa dari mikrosfer hambar dan sedikit manis. Berdasarkan penelitian oleh Almiahsari et.al. (2019), mikrosfer atenolol yang dibuat dapat menutupi rasa pahit dari atenolol sehingga mikrosfer dapat digunakan untuk menutupi rasa dari bahan aktif obat. Warna cokelat merupakan warna dari licorice dan pada FIII dihasilkan warna yang semakin pekat karena semakin tinggi konsentrasi crosslinker TPP yang digunakan (16).

Tabel 7. Hasil uji organoleptik

\begin{tabular}{|c|c|c|c|}
\hline $\begin{array}{c}\text { Uji } \\
\text { Organoleptik }\end{array}$ & FI & FII & FIII \\
\hline Warna & Cokelat muda & Cokelat & Cokelat Tua \\
\hline Rasa & $\begin{array}{c}\text { Hambar sedikit } \\
\text { manis }\end{array}$ & $\begin{array}{c}\text { Hambar sedikit } \\
\text { manis }\end{array}$ & $\begin{array}{c}\text { Hambar sedikit } \\
\text { manis }\end{array}$ \\
\hline Bau & Khas Licorice & Khas Licorice & Khas Licorice \\
\hline
\end{tabular}

\section{Uji Ukuran dan Morfologi}

Mikrosfer merupakan partikel sferis kecil dan memiliki rentang ukuran 1-1000 $\mu \mathrm{m}$ sehingga ukuran rata-rata partikel mikrosfer telah memenuhi syarat (17). Tidak terdapat perbedaan yang signifikan $(\mathrm{p}>0,05)$ (Tabel 8) namun hasil yang terlihat pada penelitian ini bahwa ukuran partikel semakin menurun dengan peningkatan konsentrasi crosslinker natrium tripolifosfat. Berdasarkan penelitian oleh Patil et.al. (2014), penurunan ukuran partikel pada peningkatan konsentrasi agen pengikat silang disebabkan karena pembentukan struktur jaringan yang lebih kaku dengan tingkat ikatan silang antara polimer dan crosslinker yang lebih tinggi (18).

Tabel 8. Hasil uji ukuran dan morfologi

\begin{tabular}{|c|c|c|}
\hline Formula & Ukuran Rata - rata Partikel & Morfologi \\
\hline F1 & $270,38 \mu \mathrm{m}$ & Sferis \\
\hline F2 & $266,43 \mu \mathrm{m}$ & Kurang sferis \\
\hline F3 & $261,17 \mu \mathrm{m}$ & Kurang sferis \\
\hline
\end{tabular}

\section{Uji Sifat Alir}

Laju alir dan sudut diam pada mikrosfer FI, FII, dan FIII dapat diamati pada tabel 9. Pada $100 \mathrm{~g}$ serbuk dikatakan memiliki laju alir yang baik bila waktu alir < 10 detik sehingga untuk 10 g serbuk diperlukan waktu $<1$ detik sehingga dari ketiga formula telah memenuhi syarat (16). Ketiga formula juga telah memenuhi syarat sudut diam $<30^{\circ}$ (16). Hasil uji evaluasi pada ketiga formula menunjukkan seluruh formula memiliki sifat alir yang baik.

Tabel 9. Hasil uji sifat alir

\begin{tabular}{|c|l|l|l|c|c|c|}
\hline $\begin{array}{c}\text { Uji } \\
\text { Evalua } \\
\text { si }\end{array}$ & \multicolumn{2}{|c|}{ FI } & \multicolumn{2}{c|}{ FII } & \multicolumn{2}{c|}{ FIII } \\
\hline $\begin{array}{c}\text { Laju } \\
\text { Alir }\end{array}$ & \multicolumn{2}{|c|}{0,16 detik } & \multicolumn{2}{c|}{0,22 detik } & \multicolumn{2}{c|}{0,42 detik } \\
\cline { 1 - 4 } $\begin{array}{c}\text { Sudut } \\
\text { Diam }\end{array}$ & $\begin{array}{l}h=0,7 \\
\mathrm{~cm}\end{array}$ & $\begin{array}{l}13,1 \\
1^{\circ}\end{array}$ & $\begin{array}{l}h=1,4 \\
\mathrm{~cm}\end{array}$ & $\begin{array}{c}24,2 \\
7^{\circ}\end{array}$ & $\begin{array}{c}h=1,4 \\
\mathrm{~cm}\end{array}$ & $23,26^{\circ}$ \\
\cline { 2 - 2 } & $\begin{array}{l}r=3 \\
\mathrm{~cm}\end{array}$ & $\begin{array}{l}r=3,1 \\
\mathrm{~cm}\end{array}$ & $\begin{array}{c}r=3,25 \\
\mathrm{~cm}\end{array}$ & \\
\hline
\end{tabular}

\section{Uji Kadar Air}

FI memenuhi hasil uji dengan kadar air $\leq 10 \%$ (15). Pada obat tradisional, kadar air yang berlebihan dapat meningkatkan pertumbuhan mikroba sehingga mempengaruhi mutu obat tradisional. Kadar air yang dihasilkan dari FI, FII, dan FIII tidak terdapat perbedaan yang bermakna $(\mathrm{p}>0,05)$ (Tabel 10).

Tabel 10. Hasil uji kadar air, uji penetapan kandungan, dan uji waktu hancur

\begin{tabular}{|c|c|c|c|}
\hline Uji Evaluasi & FI & FII & FIII \\
\hline Uji Kadar Air & $9,8 \%$ & $15,3 \%$ & $19,36 \%$ \\
\hline $\begin{array}{c}\text { Uji Penetapan } \\
\text { Kandungan }\end{array}$ & $1,29 \%$ & $0,104 \%$ & $0,249 \%$ \\
\hline Uji Waktu Hancur & 8,06 menit & $\begin{array}{c}7,22 \\
\text { menit }\end{array}$ & $\begin{array}{c}6,00 \\
\text { menit }\end{array}$ \\
\hline
\end{tabular}

\section{Uji Penetapan Kandungan}

Berdasarkan uji penetapan kandungan mikrosfer ekstrak licorice senyawa licorice (Tabel 10) didapatkan bahwa FI memiliki kandungan paling tinggi. Kandungan ekstrak dalam mikrosfer dipengaruhi oleh berbagai faktor seperti konsentrasi crosslinker dan polimer. Penurunan dari kepadatan ikatan crosslinker natrium tripolifosfat menyebabkan peningkatan ukuran partikel yang diakibatkan oleh peningkatan konsentrasi obat (19).

\section{Uji Waktu Hancur}

Uji waktu hancur pada FI, FII, FIII menghasilkan bahwa kapsul telah hancur sempurna dalam waktu $<30$ menit (Tabel 10). Uji waktu hancur untuk kapsul obat tradisional adalah < 30 menit sehingga telah memenuhi uji (13). Dalam uji evaluasi, digunakan media air yang telah dipanaskan hingga suhu $37^{\circ} \mathrm{C}$ sesuai dengan suhu tubuh manusia. Waktu hancur yang baik menandakan bahwa setelah ditelan sediaan kapsul dapat langsung hancur dengan baik sehingga dapat diperoleh efek farmakologi dalam waktu cepat (20). Dari ketiga formula, FIII memiliki waktu hancur paling cepat yakni 6 menit.

\section{Uji Keseragaman Bobot}

Hasil uji keseragaman bobot pada FI, FII, dan FIII didapatkan bahwa FI dan FII memenuhi uji keseragaman 
bobot (Tabel 11).Pada FI seluruh kapsul memenuhi tidak ada yang lebih besar dari $10 \%$ dari bobot isi rata-rata. Pada FII $<2$ kapsul yang memiliki bobot isi menyimpang dari $10 \%$ bobot rata-rata. Pada FIII terdapat $>2$ kapsul yang bobot isinya menyimpang dari bobot isi rata-rata dan tidak ada satu kapsul yang bobot isinya menyimpang dari $25 \%$ sehingga FIII tidak memenuhi persyaratan. Keseragaman bobot berkaitan dengan jumlah zat aktif yang sama dan anggapan serbuk tercampur secara homogen. Keseragaman bobot dapat dipengaruhi oleh sifat alir serbuk, pengisi, dan proses ketika pencampuran (20).

Tabel 11. Hasil uji keseragaman bobot

\begin{tabular}{|c|c|c|c|}
\hline Kapsul & FI & FII & FIII \\
\hline Kapsul 1 & $0,2034 \mathrm{~g}$ & $0,1524 \mathrm{~g}$ & $0,1648 \mathrm{~g}$ \\
\hline Kapsul 2 & $0,1892 \mathrm{~g}$ & $0,1780 \mathrm{~g}$ & $0,1490 \mathrm{~g}$ \\
\hline Kapsul 3 & $0,1861 \mathrm{~g}$ & $0,1477 \mathrm{~g}$ & $0,1722 \mathrm{~g}$ \\
\hline Kapsul 4 & $0,2033 \mathrm{~g}$ & $0,1498 \mathrm{~g}$ & $0,1783 \mathrm{~g}$ \\
\hline Kapsul 5 & $0,1901 \mathrm{~g}$ & $0,1599 \mathrm{~g}$ & $0,1506 \mathrm{~g}$ \\
\hline Kapsul 6 & $0,2008 \mathrm{~g}$ & $0,1765 \mathrm{~g}$ & $0,1410 \mathrm{~g}$ \\
\hline Kapsul 7 & $0,1878 \mathrm{~g}$ & $0,1763 \mathrm{~g}$ & $0,1554 \mathrm{~g}$ \\
\hline Kapsul 8 & $0,1874 \mathrm{~g}$ & $0,1705 \mathrm{~g}$ & $0,1726 \mathrm{~g}$ \\
\hline Kapsul 9 & $0,1863 \mathrm{~g}$ & $0,1628 \mathrm{~g}$ & $0,1729 \mathrm{~g}$ \\
\hline Kapsul 10 & $0,1721 \mathrm{~g}$ & $0,1575 \mathrm{~g}$ & $0,1657 \mathrm{~g}$ \\
\hline Kapsul 11 & $0,2012 \mathrm{~g}$ & $0,1659 \mathrm{~g}$ & $0,1540 \mathrm{~g}$ \\
\hline Kapsul 12 & $0,1859 \mathrm{~g}$ & $0,1770 \mathrm{~g}$ & $0,1490 \mathrm{~g}$ \\
\hline Kapsul 13 & $0,1721 \mathrm{~g}$ & $0,1629 \mathrm{~g}$ & $0,1580 \mathrm{~g}$ \\
\hline Kapsul 14 & $0,1968 \mathrm{~g}$ & $0,1770 \mathrm{~g}$ & $0,1804 \mathrm{~g}$ \\
\hline Kapsul 15 & $0,1732 \mathrm{~g}$ & $0,1629 \mathrm{~g}$ & $0,1683 \mathrm{~g}$ \\
\hline Kapsul 16 & $0,1868 \mathrm{~g}$ & $0,1770 \mathrm{~g}$ & $0,1773 \mathrm{~g}$ \\
\hline Kapsul 17 & $0,1859 \mathrm{~g}$ & $0,1767 \mathrm{~g}$ & $0,1520 \mathrm{~g}$ \\
\hline Kapsul 18 & $0,1926 \mathrm{~g}$ & $0,1868 \mathrm{~g}$ & $0,1568 \mathrm{~g}$ \\
\hline Kapsul 19 & $0,1811 \mathrm{~g}$ & $0,1675 \mathrm{~g}$ & $0,1534 \mathrm{~g}$ \\
\hline Kapsul 20 & $0,1977 \mathrm{~g}$ & $0,1808 \mathrm{~g}$ & $0,1245 \mathrm{~g}$ \\
\hline Bobot rata - rata & $0,1890 \mathrm{~g}$ & $0,1681 \mathrm{~g}$ & $0,1598 \mathrm{~g}$ \\
\hline
\end{tabular}

\section{Kesimpulan}

Berdasarkan penelitian yang telah dilakukan, dapat ditarik kesimpulan bahwa dari studi in silico seluruh senyawa yang terkandung dalam licorice berpotensi sebagai kandidat obat. Senyawa dalam licorice yakni glycyrrhetic acid, liquiritin apioside dan liquiritin mampu menghambat protein HMGB1 lebih kuat daripada senyawa pembanding. Binding affinity yang dihasilkan oleh ikatan antara HMGB1 dengan glycyrrhetic acid, liquiritin apioside dan liquiritin lebih kuat yakni -8,4, -7,9, dan -7,1. Glycyrrhetic acid dan licochalcone $A$ merupakan substrat CYP450 3A4kemudian delapan senyawa merupakan substrat P-gp dan merupakan senyawa dengan kelas toksisitas rendah yakni 4-5. Dari hasil pembuatan mikrosfer dengan metode gelasi ionik, formulasi 1 dengan konsentrasi crosslinkernatrium tripolifosfat $3 \%$ dengan polimer kitosan $1 \%$ paling memenuhi persyaratan uji evaluasi.

\section{Ucapan Terima Kasih}

Ucapan terima kasih berisi uacapan terima kasih kepada pihak - pihak yang membantu dalam penelitian ini.Penulis mengucapkan terima kasih kepada Direktorat Jenderal Pendidikan Tinggi dan Kementrian Pendidikan dan Kebudayaan atas pembiayaan yang telah diberikan dalam kegiatan Program Kreativitas Mahasiswa tahun 2021 serta Universitas Brawijaya yang telah memfasilitasi kami dalam penyusunan artikel ilmiah ini.

\section{Konflik Kepentingan}

Tidak ada potensi konflik kepentingan yang dilaporkan oleh penulis.

\section{Daftar Pustaka}

1. Shah R, Rosso K, Nathanson SD. Pathogenesis, prevention, diagnosis and treatment of breast cancer. World journal of clinical oncology. 2014 Aug 10;5(3):283.

2. Mathur G, Nain S, Sharma PK. Cancer: an overview. Acad. J. Cancer Res. 2015;8:1.

3. Harbeck N, Wuerstlein R. Truly personalized therapy-An end to the era of one size fits all. Nature Reviews Clinical Oncology. 2019 Feb;16(2):77-8.

4. Yoo $\mathrm{H}, \mathrm{Ku}$ SK, Baek YD, Bae JS. Anti-inflammatory effects of rutin on HMGB1-induced inflammatory responses in vitro and in vivo. Inflammation Research. 2014 Mar;63(3):197-206.

5. Modarresi M, Hajialyani M, Moasefi N, Ahmadi F, Hosseinzadeh L. Evaluation of the cytotoxic and apoptogenic effects of glabridin and its effect on cytotoxicity and apoptosis induced by doxorubicin toward cancerous cells. Advanced pharmaceutical bulletin. 2019 Aug;9(3):481.

6. Lee SK, Park KK, Park JH, Lim SS, Chung WY. The inhibitory effect of roasted licorice extract on human metastatic breast cancer cell-induced bone destruction. Phytotherapy Research. 2013 Dec;27(12):1776-83.

7. Parade NN, Pradjoko I. Manajemen Ekstravasasi Kemoterapi. Jurnal Respirasi. 2019 Jan 30;5(1):15-21.

8. Sahil K, Akanksha M, Premjeet S, Bilandi A, Kapoor B. Microsphere: A review. Int. J. Res. Pharm. Chem. 2011;1(4):1184-98.

9. Noguez Méndez NA, Quirino-Barreda CT, et al. Design and development ofpharmaceutical microprocesses in the production ofnanomedicine. Ch. 22. Nanostructures of Oral Medicine. 2017.

10. EnriquezGG, Brandon AO, Syed AAR, Duc PD. Formulation development and in vitro evaluation of oral extended-release capsules containing biodegradable microspheres. Journal of Nanomedicine and Nanotechnology. 2014; 5 (3).

11. Ardiana R, Khasanah DU, Permatasari D, Adianingsih OR. Molecular Docking Study of Active Compounds in Amaranthus tricolor Leaves as High Mobility Group Box 1 (HMGB1) Inhibitor in Breast Cancer. JSMARTech: Journal of Smart Bioprospecting and Technology. 2020 Nov 30;2(1):028-34.

12. Benet LZ, Hosey CM, Ursu O, Oprea TI. BDDCS, the rule of 5 and drugability. Advanced drug delivery reviews. 2016 Jun 1;101:89-98.

13. Kesuma D, Siswandono S, Purwanto BT, Rudyanto M. 
Docking, synthesis and cytotoxic test on Human Breast Cancer cell line T47D of N-(phenylcarbomothyoil)-benzamide. World Journal of Pharmaceutical Research. 2018;7(7):70-8.

14. Pastorino G, Cornara L, Soares S, Rodrigues F, Oliveira MB. Liquorice (Glycyrrhiza glabra): A phytochemical and pharmacological review. Phytotherapy research. 2018 Dec;32(12):2323-39.

15. BPOM. 2019. Persyaratan Keamanan dan Mutu Obat Tradisional. Peraturan BPOM Nomor 32 Tahun 2019.

16. Almiahsari A, Danimayostu AA, Permatasari D. Pengaruh rasio kitosan dan atenolol terhadap karakteritik fisik dan profil pelepasan pada mikrosfer atenolol. Pharmaceutical Journal of Indonesia. 2019 Jan 24;4(1):1-9.

17. Kalpna M, Dev D, Shahnaz M, Parkash J, Prasad DN. Preparation of controlled release metformin hydrochloride loaded chitosan microspheres and evalaution of formulation parameters. Journal of Drug Delivery and Therapeutics. 2018 Oct 15;8(5-s):378-87.

18. Patil SS, Mohan Gupta VR, Gupta SK, Hiremath D. Formulation and characterization of TPP cross-linked chitosan microspheres loaded with lornoxicam. J Biomed Pharm Res. 2014;3:51-8.

19. Tilkan MG, Özdemir N. Investigation of the parameters affecting the release of flurbiprofen from chitosan microspheres. Brazilian Journal of Pharmaceutical Sciences. 2018 Apr 9;53.

20. Farida S, Mana TA, Dewi TF. Karakteristik Mutu Kapsul Ramuan Kebugaran untuk Saintifikasi Jamu. Jurnal Tumbuhan Obat Indonesia. 2019 Aug 30;12(1):25-32. 